\title{
The Impact of Environmental Regulation on the Domestic Value Added Rate of China's Industrial Exports-Empirical Test Based on Panel Data of Prefecture Level Cities
}

\author{
Jingjing Huang \\ Business School, Nanjing Normal University, Nanjing, China \\ Email:1229986059@qq.com
}

How to cite this paper: Huang, J. J. (2020). The Impact of Environmental Regulation on the Domestic Value Added Rate of China's Industrial Exports-Empirical Test Based on Panel Data of Prefecture Level Cities. American Journal of Industrial and Business Management, 10, 1437-1453.

https://doi.org/10.4236/ajibm.2020.108094

Received: July 29, 2020

Accepted: August 22, 2020

Published: August 25, 2020

Copyright $\odot 2020$ by author(s) and Scientific Research Publishing Inc. This work is licensed under the Creative Commons Attribution International License (CC BY 4.0).

http://creativecommons.org/licenses/by/4.0/

(c) (i) Open Access

\begin{abstract}
Environmental protection and the promotion of export domestic value-added rate is a hot issue in economic development. This paper first explores the mechanism of environmental regulation on domestic value-added rate of export, and then empirically tests the impact of environmental regulation on domestic value-added rate of industrial export in China by using panel data of 270 prefecture level cities from 2003 to 2016. In the sample period, the intensity of environmental regulation has a non-linear impact on the export domestic value-added rate. With the increase of environmental regulation intensity, the export domestic value-added rate shows a U-shaped relationship. In the eastern, central and western regions, the impact of environmental regulation on export domestic value-added rate is consistent with the overall results. However, it is not significant in the western region. This study provides enlightenment for the government to formulate and implement appropriate environmental regulation policies according to regional development differences.
\end{abstract}

\section{Keywords}

Environmental Regulation, Export, Domestic Value Added Rate

\section{Introduction}

Since the reform and opening up, export trade has gradually become one of the important sources of China's economic growth. According to the data released by the General Administration of Customs of China, the total import and export 
value of China's goods trade in 2019 was 31.54 trillion Yuan, an increase of 3.4\% compared with that in 2018. Among them, the export volume was 17.23 trillion Yuan, an increase of 5\%. However, China's position in the global value chain cannot be accurately reflected by the total export trade. The export domestic value-added rate can avoid many repeated calculations and better reflect a country's actual gains in world trade. According to the OECD database, the average value-added rate of China's export in 2016 was about $76 \%$. Compared with developed countries, there is still a certain gap. It is of great significance for China to upgrade its position in the global value chain by increasing the domestic value-added rate of exports.

Industry plays an irreplaceable role in the process of China's economic development. While the extensive development mode dominated by industry promotes the growth of export, it also brings serious environmental pollution problems to China and accelerates the deterioration of ecological environment. This growth mode of sacrificing environment for the sake of economic development is contrary to the concept of sustainable development. After realizing that the pollution control mode of "pollution first and treatment later" can not alleviate the serious pollution caused by industry, the state promulgated the "Cleaner Production Promotion Law" in 2002, marking the transformation of China's pollution control mode from terminal treatment to whole process control (Zhang \& Liu, 2019). The 19th National Congress of the Communist Party of China proposed for the first time that "green waters and green mountains are golden mountains and silver mountains, and adhere to the basic national policy of resource conservation and environmental protection". The formulation and implementation of environmental regulation policies are indispensable in production and life.

The research on the relationship between environmental regulation and foreign trade is of practical significance for how to form a good balance between environmental regulation and export. Compared with the total export, the domestic value-added rate of export can reflect the actual trade gains more accurately. Then, how does the environmental regulation affect the domestic value-added rate of China's industrial exports? What is the impact mechanism? These are the issues to be studied in this paper.

This paper discusses the mechanism of environmental regulation on export domestic value-added rate, and makes an empirical test based on the panel data of 270 prefecture level cities in China from 2003 to 2016. The results show that: 1) the intensity of environmental regulation has a nonlinear effect on the export domestic value-added rate. With the increase of environmental regulation intensity, the export domestic value-added rate first decreases and then increases. 2) In the eastern, central and western regions, the impact of environmental regulation on domestic value added rate of export is consistent with the overall results. However, the effect of the regulation on the environmental value-added in the western region is not consistent with that in the western region. 
The marginal contribution of this paper is as follows. First, there is no consensus on the impact of environmental regulation on export trade at present. This paper studies the impact mechanism of environmental regulation on the domestic value added rate of China's industrial exports from the level of prefecture level cities and conducts empirical test, it may provide a new empirical evidence for the study of the impact of environmental regulation on China's trade gains. Secondly, based on the region, this paper studies the heterogeneous impact of environmental regulation on domestic value-added rate of export, and provides effective suggestions for the improvement of environmental regulation policy, which is conducive to the sustainable development of ecological environment and export trade.

The remainder of the paper is structured as follows. Section 2 is literature review. Section 3 discusses the mechanism of environmental regulation on export domestic added value. Section 4 constructs the empirical model, selects variables and explains the data source. Section 5 analyzes the empirical results and robustness test; the third part discusses the impact mechanism of environmental regulation on export domestic added value. Section 6 is the conclusion and policy suggestions.

\section{Literature Review}

For a long time, the research on the relationship between environmental regulation and export has been a hot topic in academic circles at home and abroad. Scholars mainly focus on two theories: one is "Pollution refuge hypothesis"; the other is "Porter Hypothesis".

"Pollution refuge hypothesis" is the concept of "pollution paradise" first put forward by Walter (1982) when studying the impact of foreign investment on the carbon emissions of host countries. He thinks that under the condition of free trade, developing countries may reduce the environmental regulation standards to attract foreign investment. As a result, industries with high energy consumption, high pollution and high emission are transferred from developed countries with higher environmental regulation standards to developing countries, and developing countries have gradually become the "paradise" of pollution industries. This theory is based on the assumption that "environmental regulations will increase the cost of export enterprises". Porter and van der Linde pointed out in 1995 that strict but well-designed environmental regulations can stimulate enterprise innovation, partially or even completely offset the cost of complying with environmental regulations, so that manufacturers have more competitive advantages in the world market (Porter \& van der Linde, 1995). This view is called "Porter Hypothesis". Porter's hypothesis is dedicated to seeking a common development mode of environmental protection and foreign trade. It provides us with a new perspective.

The existing literature mainly analyzes the above theories from the following perspectives. First, from the perspective of export quality. Wang et al. (2019a) 
used the data of China's micro enterprises from 2000 to 2006, and found that environmental regulation has a significant role in promoting the quality of export products, and with the improvement of product quality, environmental regulation has a significant impact on the quality of export products. Wang et al. (2016) used the international trade data from 1985 to 2010, and used feasible generalized least squares (FGLS) and surface independent regression (SUR) methods to conduct empirical analysis. The results show that under strict environmental regulations, environmental regulation can promote the degree of Embeddedness and division of labor status of enterprises in the global value chain. Li \& Du (2018) concluded that environmental regulation can promote the improvement of export quality of enterprises, but with the increase of regional fiscal decentralization and official corruption degree, environmental regulation can reduce the export quality of enterprises. $\mathrm{Hu}$ (2019) took the cleaner production industry standards issued by the Ministry of environmental protection of China since 2006 as a case study, and found that environmental regulations for cleaner production would reduce product quality in the short term. However, in the long run, the impact of environmental regulation on product quality has gradually changed from negative to positive. Xie \& Liu (2018) used the industry panel data of China's manufacturing industry and used the systematic GMM estimation method to empirically test that, for the industry with a large proportion of fixed asset investment in factor input, there is a significant " $U$ " dynamic relationship between environmental regulation policy and industry export quality. For industries with a small proportion of fixed asset investment, the relationship between environmental regulation and export quality presents a " $\mathrm{J}$ " type feature of increasing marginal impact.

Second, from the perspective of comparative advantage. Lu (2009) based on the sample of 95 countries in 2005, using the HOV model, found that more stringent environmental regulations will enhance the comparative advantage of some pollution intensive goods. Dong et al. (2011) constructed an input-output model with the cost of pollution control, found that environmental regulationhas a limited impact on the international competitiveness of Chinese products. Greenstone et al. (2012) found that environmental regulation had a certain degree of negative impact on competitiveness by using the data of American manufacturing enterprises from 1972 to 1993. Li et al. (2012) used the panel data of China's industrial industry from 1998 to 2008, and concluded that environmental regulation is conducive to the improvement of comparative advantage of industrial industry.

Thirdly, from the aspect of export technology complexity. Zhou (2015) calculated the export technology complexity of 28 provincial levels in China from 2002 to 2008 based on HS category data and modified Hausmann model. Environmental regulation has a significant positive impact on export technology complexity. Pu (2015) used the panel data of industrial industry from 2002 to 2012 and tested it with the System GMM method. It was found that there was a 
"dynamic inertia" feature in the export domestic technology complexity, and the increase of environmental regulation intensity would promote the export complexity. Yang (2016) studied from the perspective of regional heterogeneity. Overall, environmental regulation is conducive to the improvement of China's export technology complexity; there is a " $U$ " type relationship between environmental regulation and export technology complexity in the eastern and western regions, while there is a simple linear relationship in the western region. Xiao \& Chen (2019) selected the data of 30 provinces in China from 2003 to 2010, and used Hansen's nonlinear panel data threshold model. There is a moderate range of environmental regulation intensity, in which the promotion effect of environmental regulation on the upgrading of export technology complexity is the greatest. Too low or too high regulation level is not conducive to the upgrading of export technology complexity.

\section{Theoretical Analysis}

Under the background of economic globalization, the international division of labor has become more and more profound. In the production process of a country's export products, it is very unlikely to use domestic intermediate inputs only. It is often necessary to import products from other countries for production input. It is very important to distinguish between domestic direct supply of intermediate input and import intermediate input to calculate the export domestic value-added rate. We will explore how environmental regulation affects the domestic value-added rate of export by influencing the investment of intermediate goods. Generally speaking, environmental regulation affects the domestic value-added rate of export mainly through "cost effect" and "innovation effect".

First of all, "cost effect". According to neoclassicism, under the goal of maximizing profits and minimizing costs, environmental regulations make enterprises increase investment in pollution control, which will squeeze out a part of production costs (Wanley \& Whitehead, 1994). However, some enterprises with serious pollution and unable to pay the cost of pollution control can only choose to stop production, reduce losses, and finally withdraw from the market. As a whole, the number of enterprises in the market decreases (Wang et al., 2019b). Some enterprises in the market use intermediate inputs and some produce intermediate inputs. The number of intermediate inputs in China decreases, and the relative price of domestic intermediate products increases. The enterprises that remain in the market to produce intermediate inputs also reduce the marginal income of improving quality due to the increase of production costs (Fan et al., 2013), and enterprises have no incentive to produce higher quality products (Peng et al., 2016). In order to reduce the cost, the enterprises that stay in the market and need to use intermediate inputs will choose to purchase cheaper and higher quality imported intermediate inputs for production, which will reduce the domestic value-added rate of exports. 
Secondly, "innovation effect". The core point of Porter's hypothesis is that proper and strict environmental regulations can force enterprises to carry out technological innovation, increase technological development and technological transformation activities, such as developing new materials and new technologies, updating equipment and production lines (Zhang \& Song, 2019), so as to make production technology progress. In the first place, environmental regulation promotes the technological progress of enterprises and improves the production efficiency (Zhang \& Bu, 2011). The output of direct intermediate inputs in China increases, and the relative price of domestic intermediate products decreases. In order to save production costs, enterprises using intermediate inputs tend to choose domestic intermediate inputs, which reduces the demand for imported intermediate inputs. In the next place, through technological innovation, the quality of products has been improved (Sheng \& Zhang, 2017), and the domestic intermediate inputs produced are more favored by manufacturers, and they are more likely to purchase domestic intermediate inputs. In addition, technological progress of enterprises also makes input factors more environmentally friendly, reduces pollution and changes product portfolio behavior (Elrod \& Malik, 2017). If domestic intermediate inputs are more conducive to environmental protection, manufacturers who need to use intermediate products will choose to buy more domestic intermediate products to invest in production. In short, environmental regulations encourage enterprises to innovate, which makes the domestic direct supply of intermediate inputs more affordable and high-quality, and the demand of export enterprises increases, which increases the proportion of domestic intermediate inputs in the total intermediate inputs, and then value added rate of export trade can be improved.

To sum up, the impact of environmental regulation on domestic value-added rate of export depends on the total effect of cost effect and innovation effect, while the cost effect is negative for the total effect. Therefore, the impact of environmental regulation intensity on export domestic value-added rate is uncertain.

\section{Model Setting and Data Description}

\subsection{Model Setting}

Based on the previous analysis and related studies, considering that the explained variables are gradually changing and accumulating, this paper adds the explanatory variables to the econometric model with a lag period. In order to study the uncertain impact of environmental regulation on the export domestic value-added rate, the environmental regulation variable (ers) is introduced into the model. The dynamic panel model is constructed as follows:

$$
\begin{aligned}
d \operatorname{var}_{i, t}= & \beta_{0}+\beta_{1} d v a r_{i, t-1}+\beta_{2} \operatorname{ers}_{i, t}+\beta_{3}\left(\operatorname{ers}_{i, t}\right)^{2} \\
& +\psi X+\eta_{i}+\gamma_{t}+\varepsilon_{i, t}
\end{aligned}
$$

Among them, $i$ on behalf of prefecture level cities, $t$ Represents the year, 
dvar Represents the domestic value added rate of industrial exports, ers represents the intensity of environmental regulation, $X$ Represents other control variables; $\eta_{i}$ captures the individual fixed effect of a city which does not change with years; $\gamma_{t}$ captures the time fixed effect that does not change with the city in a certain year; $\varepsilon_{i, t}$ is a random error term.

\subsection{Variable Description}

1) The intensity of environmental regulation

There is no unified standard for measuring the intensity of environmental regulation. At present, there are several types of measurement indicators: enterprise pollution reduction cost (Levinson, 1996; Lanoie et al., 2008; Zhang et al., 2011); comprehensive index of pollutant emission (Zhu et al., 2011; Li \& Tao, 2012); energy price, such as market-based carbon tax, is converted into higher energy price (Aldy \& Pizer, 2015); The number of environmental protection organizations (Bu et al., 2013) and the number of environmental regulations and policies (Wei, 2001) were analyzed. This paper uses the method of Shen et al. (2017) to construct the comprehensive index of environmental regulation (ers). The specific steps are as follows:

Firstly, the sulfur dioxide removal rate and industrial smoke (dust) removal rate are constructed

$$
U E R_{i j}=R_{i j} / D_{i j}
$$

$U E R_{i j}$ is a single indicator of environmental regulation, which means the emission standard rate of pollutants $j$ in city $i ; R_{i j}$ indicates that the pollutant emission of single index reaches the scalar level; $D_{i j}$ represents the pollutant emission in a single indicator; $i$ represents different cities $(i=1,2, \cdots, n) ; j$ represents different pollutants $(j=1,2, \cdots, m)$.

Secondly, the sulfur dioxide removal rate and industrial smoke (dust) removal rate were standardized:

$$
C E R_{i j}=\left[U E R_{i j}-\min \left(U E R_{j}\right)\right] /\left[\max \left(U E R_{j}\right)-\min \left(U E R_{j}\right)\right]
$$

$U E R_{i j}$ denotes the class $j$ index original value in city $i, \max \left(U E R_{j}\right)$ and $\min \left(U E R_{j}\right)$ respectively represent the maximum and minimum values of class $j$ index in all cities, $C E R_{i j}$ denotes the standardized value of class $j$ index in city $i$.

Then, the adjustment coefficient $W_{i j}$ is calculated for the two single indicators of each city. Due to the differences in the industrial development status of cities, the proportion of industrial sulfur dioxide and smoke (powder) dust emission will also be different, and the emission degree of different types of pollutants in the same city will be different, so it is necessary to give different weights to each pollution emission index of each city (Shen et al., 2017) to accurately reflect the degree of pollution control of each city. The method of calculating adjustment coefficient $W_{i j}$ is as follows:

$$
W_{i j}=\frac{C E R_{i j}}{\Sigma_{i} C E R_{i j}} / \frac{G D P_{i}}{\sum_{i} G D P_{i}}
$$


$W_{i j}$ means the ratio of the proportion of pollutants $j$ discharged by city $i$ in the total amount of pollutants to the proportion of GDP of city $i$ in national GDP.

Finally, according to the standard value and adjustment coefficient of industrial sulfur dioxide removal rate and industrial smoke (powder) dust removal rate $W_{i j}$, we can get the degree of environmental regulation $\operatorname{ers}_{i}=\sum_{j=1}^{2} W_{i j} C E R_{i j} / 2$.

2) Calculation of domestic value added rate of export trade

Domestic value added rate of export trade is the proportion of export trade added value in total export value, and export trade added value refers to the domestic value added part of a country's total export value. In this paper, the domestic value-added rate of exports is calculated based on the non competitive input-output table (I-O table) of China's provinces. The research on the measurement of trade value-added began with Hummels et al. (2001). They first proposed to use the proportion of imported intermediate goods in export products to reflect the vertical specialization degree of a country. However, the basic assumption of this method is that the proportion of import input in the production of domestic final consumer goods is the same as that in export products. The HIY method may overestimate the domestic added value of exports. Koopman et al. (2012) improved this method by decomposing the non competitive I-O table into general trade and processing trade I-O tables. They also divided a country's exports into three parts: export trade value-added, foreign added value and domestic added value of intermediate products export to China (Zheng \& Yu, 2014).

The balance of non competitive input-output table is as follows:

$$
\begin{gathered}
A^{D} X+Y^{D}=X \\
A^{M} X+Y^{M}=M \\
E A^{D}+E A^{M}+A_{V}=E
\end{gathered}
$$

Among them, $A^{D}$ is the direct consumption coefficient matrix of $n \times n$ domestic intermediate inputs, $A^{M}$ is the direct consumption coefficient matrix of $n \times n$ imported intermediate inputs; $Y^{D}$ and $Y^{M}$, the column vectors are used for domestic and imported final products respectively; $X$ and $M$, the column vectors of domestic total output and import are expressed respectively; $E$ is $1 \times n$ identity matrix, $A_{V}$ is $1 \times n$ value added rate matrix of each department. Intermediate input can be divided into domestic intermediate input and import intermediate input. In the non competitive input-output table of each province in China, the import proportion of intermediate goods input in each industry is not known. This paper uses the method of Zheng \& Yu (2014) for reference, and assumes that the proportion of import and domestic production in intermediate goods is equal to the proportion of import in final use products and domestic production. In other words, the import proportion of intermediate inputs is equal to (import of final products)/(total output + import export). According to the equilibrium relation in the non competitive input-output table: $A^{D}+A^{M}=A, A$ is the direct 
consumption coefficient matrix. $A^{M}$ can be obtained by using $\lambda$ to multiply $A$. Further, it can be concluded that $A^{D}$.

According to the proportion of domestic intermediate inputs and the total intermediate inputs, the domestic intermediate inputs can be calculated. Then, according to the statistical yearbooks of each province, the export delivery value of each industry can be obtained, and then the export domestic value-added rate of each industry can be calculated. Finally, the export domestic value-added rate of each province can be obtained by summing up.

3) Control variables

Foreign direct investment (FDI) is an important factor affecting the domestic value-added rate of exports. This paper uses the ratio (percentage) of foreign direct investment and GDP of all cities to measure. Human capital, this paper refers to the method of Li and Yin (2017), using average number of years of education to express. In this paper, the rd is represented by the ratio of sum of expenditure on science and technology and education to GDP. The lnkl is expressed by the logarithm of the ratio of the annual average net fixed assets to the average annual employees of the industry in each city. The lnsize is conveyed by the logarithm of the total industrial output value of each city.

\subsection{Data Description}

The data sample of this paper consists of panel data of 270 cities at prefecture level and above in China from 2003 to $2016^{1}$. The data needed to calculate the core explanatory variables and the data of the control variables are all from the statistical yearbook of China's cities and the statistical yearbooks of each province. The amount of foreign direct investment of each city is calculated by the exchange rate of US dollar to RMB published every year. The exchange rate is from the official website of the National Bureau of statistics. Therefore, according to the input-output table of 30 provinces in China, the export domestic value-added rate is calculated $^{2}$. The statistical description of each variable is shown in Table 1.

\section{Empirical Analysis}

Since the lag term of the explained variables is added to the model, it will lead to endogenous problems. Therefore, this paper uses the system generalized moment estimation method (sys-gmm) to carry out stepwise regression on the model, and uses AR (1), AR (2) test and sargan test to determine the rationality

\footnotetext{
${ }^{1}$ Due to the adjustment of administrative divisions and lack of data in the sample period, Chaohu, Bijie, Tongren, Haikou, Sansha, Danzhou, Haidong, Lhasa, Jiayuguan, Jinchang, Baiyin, Zhongwei, Tianshui, Wuwei, Zhangye, Pingliang, Qingyang, Dingxi, Wuzhong, Guyuan and Karamay were excluded.

${ }^{2}$ The published input-output tables are 2002, 2007 and 2012 respectively. Since the input-output table of 2002 is a competitive input-output table, and there is no distinction between import and export, it is impossible to calculate the import intermediate input ratio. Therefore, this paper assumes that the import intermediate input proportion in 2002 is equal to that in 2007, The proportion of domestic intermediate input in 2003-2006 is obtained from the input-output table of each region in 2002 , that of 2007-2011 is obtained from the input-output table of each region in 2007, and that of 2012-2016 is obtained from the input-output table of each region in 2012.
} 
of the model setting and whether the tool variables are effective and over identified.

\subsection{Full Sample Estimation}

The regression results in Table 2 are analyzed as follows. 1) The regression coefficient of the first-order lag term of the explained variable dvar is significantly positive in all estimation models, which indicates that the setting of the dynamic panel model in this paper is reasonable. 2) In model 2, the coefficient of the first-order term of the core explanatory variable ers is significantly negative, and the coefficient of the second-order term is significantly positive. The reason may be that the cost effect of environmental regulation is greater than the innovation effect. In order to save costs, enterprises choose to buy more imported intermediate products instead of domestic intermediate products to produce export products. With the implementation of environmental policies more strictly, the innovation effect is greater than the cost effect, the quality of domestic intermediate products is better and the price is lower, the enterprises will increase their purchase, and then the intensity of environmental regulation will promote the increase of domestic value-added rate of export and import. 3) The coefficient of FDI is negative, but not significant. The negative coefficient may be because the inflow of FDI has intensified domestic competition, and domestic export enterprises have reduced their scale in order to reduce losses ( $\mathrm{Li}, 2019) .4$ ) The regression coefficient of human capital is positive, which indicates that human capital has a positive impact on the domestic value-added rate of export. 5) the regression coefficient of $\mathrm{R} \& \mathrm{D}$ investment is significantly negative, which may be due to the fact that China's $\mathrm{R} \& \mathrm{D}$ model is mainly imitative innovation, and the proportion of independent innovation is relatively small, and R \& D expenses are mostly used to purchase technology to imitate (Yang, 2016). 6) The regression coefficient of capital intensity lnkl is significantly negative, which may be due to the fact that the higher the capital intensity is, the less fully utilized it

Table 1. Descriptive statistics of variables.

\begin{tabular}{ccccccc}
\hline Variable & Meaning & Obs & Mean & Std. Dev & Min & Max \\
\hline dvar & Export domestic value added rate & 3780 & 0.562 & 0.0900 & 0.288 & 0.731 \\
ers & Environmental regulation intensity & 3780 & 1.448 & 2.119 & 0.001 & 51.92 \\
fdi & Foreign direct investment & 3780 & 2.127 & 2.245 & 0.001 & 20.11 \\
human & Human capital & & & & & 12.96 \\
rd & Investment in scientific research & 3780 & 2.900 & 1.510 & 0.273 & 33.16 \\
lnkl & Capital intensity & 3780 & 12.27 & 0.781 & 5.663 & 15.77 \\
lnsize & Enterprise scale & 3780 & 16.13 & 1.374 & 11.35 & 19.60 \\
\hline
\end{tabular}

Data source: stata 15.0 calculation and collation. 
Table 2. Full sample regression results of the impact of environmental regulation on export domestic value added rate.

\begin{tabular}{|c|c|c|c|c|c|c|c|}
\hline & Model 1 & Model 2 & Model 3 & Model 4 & Model 5 & Model 6 & Model 7 \\
\hline L.dvar & $\begin{array}{c}0.867^{\star * *} \\
(0.003)\end{array}$ & $\begin{array}{c}0.865^{* * *} \\
(0.003)\end{array}$ & $\begin{array}{c}0.887^{* * *} \\
(0.028)\end{array}$ & $\begin{array}{c}0.850^{* * *} \\
(0.017)\end{array}$ & $\begin{array}{c}0.859^{* * *} \\
(0.013)\end{array}$ & $\begin{array}{c}0.872^{\star * *} \\
(0.017)\end{array}$ & $\begin{array}{c}0.862^{* * *} \\
(0.013)\end{array}$ \\
\hline ers & $\begin{array}{c}-0.010^{\star *} \\
(0.035)\end{array}$ & $\begin{array}{c}-0.015^{\star * *} \\
(0.038)\end{array}$ & $\begin{array}{c}-0.097^{* * *} \\
(0.029)\end{array}$ & $\begin{array}{c}-0.041^{* * *} \\
(0.015)\end{array}$ & $\begin{array}{c}-0.026^{* *} \\
(0.013)\end{array}$ & $\begin{array}{c}-0.045^{\star * *} \\
(0.017)\end{array}$ & $\begin{array}{c}-0.021^{* *} \\
(0.006)\end{array}$ \\
\hline ers2 & & $\begin{array}{l}0.003^{* *} \\
(0.001)\end{array}$ & $\begin{array}{l}0.041^{\star *} \\
(0.018)\end{array}$ & $\begin{array}{l}0.014^{* *} \\
(0.006)\end{array}$ & $\begin{array}{l}0.009^{*} \\
(0.005)\end{array}$ & $\begin{array}{l}0.016^{\star *} \\
(0.007)\end{array}$ & $\begin{array}{l}0.004^{\star *} \\
(0.015)\end{array}$ \\
\hline fdi & & & $\begin{array}{c}-0.010^{\star} \\
(0.056)\end{array}$ & $\begin{array}{c}-0.029^{\star \star} \\
(0.121)\end{array}$ & $\begin{array}{c}-0.018^{\star \star} \\
(0.086)\end{array}$ & $\begin{array}{c}-0.030^{\star *} \\
(0.014)\end{array}$ & $\begin{array}{c}-0.034^{\star} \\
(0.044)\end{array}$ \\
\hline human & & & & $\begin{array}{l}0.047^{\star} \\
(0.025)\end{array}$ & $\begin{array}{l}0.042^{\star} \\
(0.022)\end{array}$ & $\begin{array}{c}0.021 \\
(0.019)\end{array}$ & $\begin{array}{l}0.024^{*} \\
(0.025)\end{array}$ \\
\hline $\mathrm{rd}$ & & & & & $\begin{array}{c}-0.013^{*} \\
(0.007)\end{array}$ & $\begin{array}{c}-0.028^{\star * *} \\
(0.009)\end{array}$ & $\begin{array}{c}-0.018^{* * *} \\
(0.007)\end{array}$ \\
\hline $\operatorname{lnkl}$ & & & & & & $\begin{array}{c}-0.029^{*} \\
(0.017)\end{array}$ & $\begin{array}{c}-0.031^{\star} \\
(0.016)\end{array}$ \\
\hline lnsize & & & & & & & $\begin{array}{c}-0.027^{\star *} \\
(0.014)\end{array}$ \\
\hline _cons & $\begin{array}{c}0.082^{* * *} \\
(0.021)\end{array}$ & $\begin{array}{c}0.083^{\star * *} \\
(0.022)\end{array}$ & $\begin{array}{c}0.076^{\star * *} \\
(0.016)\end{array}$ & $\begin{array}{l}0.058^{\star} \\
(0.023)\end{array}$ & $\begin{array}{l}0.058^{\star *} \\
(0.022)\end{array}$ & $\begin{array}{c}0.154^{\star * *} \\
(0.032)\end{array}$ & $\begin{array}{c}0.159^{* * *} \\
(0.027)\end{array}$ \\
\hline $\mathrm{N}$ & 3510 & 3510 & 3510 & 3510 & 3510 & 3510 & 3510 \\
\hline $\mathrm{AR}(1)$ test & $\begin{array}{c}-8.47 \\
{[0.000]}\end{array}$ & $\begin{array}{c}-8.46 \\
{[0.000]}\end{array}$ & $\begin{array}{c}-8.31 \\
{[0.000]}\end{array}$ & $\begin{array}{c}-8.03 \\
{[0.000]}\end{array}$ & $\begin{array}{c}-8.38 \\
{[0.000]}\end{array}$ & $\begin{array}{c}-7.99 \\
{[0.000]}\end{array}$ & $\begin{array}{c}-7.72 \\
{[0.000]}\end{array}$ \\
\hline $\mathrm{AR}(2)$ test & $\begin{array}{c}-1.52 \\
{[0.130]}\end{array}$ & $\begin{array}{c}-1.60 \\
{[0.110]}\end{array}$ & $\begin{array}{c}-1.47 \\
{[0.323]}\end{array}$ & $\begin{array}{c}-0.49 \\
{[0.623]}\end{array}$ & $\begin{array}{c}-0.61 \\
{[0.539]}\end{array}$ & $\begin{array}{c}-0.41 \\
{[0.679]}\end{array}$ & $\begin{array}{c}-0.29 \\
{[0.775]}\end{array}$ \\
\hline Sargan test & $\begin{array}{c}13.25 \\
{[0.351]}\end{array}$ & $\begin{array}{c}12.53 \\
{[0.404]}\end{array}$ & $\begin{array}{c}26.17 \\
{[0.293]}\end{array}$ & $\begin{array}{c}32.51 \\
{[0.541]}\end{array}$ & $\begin{array}{c}37.64 \\
{[0.350]}\end{array}$ & $\begin{array}{c}41.56 \\
{[0.446]}\end{array}$ & $\begin{array}{c}39.30 \\
{[0.412]}\end{array}$ \\
\hline
\end{tabular}

The value in () is the robust standard error of clustering; the value in [] is the p value of the corresponding statistics; $^{*},{ }^{* *}$, and ${ }^{* * *}$ indicate significance at the $1 \%, 5 \%$ and $10 \%$ confidence levels.

is, and there is a large amount of idle capital; and capital has the law of diminishing marginal efficiency (Chen \& Yang, 2018). 7) The regression coefficient of of enterpriseslnsize is significantly negative, which is consistent with the research conclusions of Liu \& Xie (2018), indicating that the larger the enterprise size, the less conducive to the increase of domestic value-added rate of export. The reason for this phenomenon may be that the larger the scale of enterprises, the higher the participation of large-scale export enterprises in the world economy. More intermediate products are used from abroad, which reduces the domestic value-added rate of export. 


\subsection{Regional Inspection}

The results of full sample estimation show that the impact of environmental regulation on the domestic value-added rate of export is U-shaped, but China's economic development is unbalanced. We divide China into eastern, central and western regions ${ }^{3}$ to investigate whether there are regional differences in the export domestic value-added rate of environmental regulation.

Table 3 shows the empirical results of different regions. 1) The impact of environmental regulations on the domestic value-added rate of exports in the eastern, central and western regions is U-shaped, but not significant in the western region. The reason may be that the industry in the western region is still in the initial stage, and the implementation of environmental regulation policies has no obvious impact on industrial development, while the industrial development in the eastern and central regions is relatively mature. Industrial development has brought huge economic benefits, but also caused great pressure on the environment. If the environmental regulation policy is not strictly implemented, the environmental pollution will be more serious, which is not conducive to sustainable development. The reasonable explanation is that the eastern region is the first region in China to open to the outside world, and the degree of opening up is also higher, and the competition between foreign-funded enterprises and domestic enterprises is more intense. It is not conducive to the export of domestic enterprises and the increase of domestic value-added rate. The FDI inflow in the central and western regions is relatively small, and the FDI inflow in these two regions presents more demonstration effect and technology spillover effect, so it can promote the domestic value-added rate of export (Li, 2019). 2) The regression coefficient of $\mathrm{rd}$ in eastern China is significantly positive. However, the regression coefficient in the central and western regions is significantly negative. The reason for this difference is that the existing technology in the eastern region can meet the demand of production capacity, and the funds are mostly used to develop new environmental protection technologies, while the production efficiency of the central and Western regions has not yet reached the required standard. 3) The regression coefficient of human capital in the three regions is the same as that in the whole sample. 4) The regression coefficient of capital intensitylnkl in the eastern region is significantly negative, while that in the central and western regions is significantly positive, which may be due to the fact that the capital intensity in the eastern region is higher and can not be fully utilized. 5) The coefficient of lnsize in eastern region is significantly negative, while the coefficient of enterprise scale in central and western regions is significantly positive. The intermediate inputs used by export enterprises often come from all over the world.

${ }^{3}$ The eastern region includes 11 provinces (cities) including Beijing, Tianjin, Hebei, Liaoning, Shanghai, Jiangsu, Zhejiang, Fujian, Shandong, Guangdong and Hainan; the central region includes 8 provinces (cities) including Shanxi, Jilin, Heilongjiang, Anhui, Jiangxi, Henan, Hubei and Hunan; The western region includes 12 provinces (cities and autonomous regions) in Inner Mongolia, Guangxi, Chongqing, Sichuan, Guizhou, Yunnan, Tibet, Shaanxi, Gansu, Qinghai, Ningxia, and Xinjiang. 
Table 3. Grouping regression results of environmental regulation impact on $d v a r$.

\begin{tabular}{|c|c|c|c|}
\hline & East & Central section & West \\
\hline L.dvar & $\begin{array}{c}0.839^{* * *} \\
(0.057)\end{array}$ & $\begin{array}{c}0.873^{\star * *} \\
(0.019)\end{array}$ & $\begin{array}{c}0.846^{\star * *} \\
(0.035)\end{array}$ \\
\hline ers & $\begin{array}{c}-0.031^{\star *} \\
(0.049)\end{array}$ & $\begin{array}{c}-0.011^{\star * *} \\
(0.024)\end{array}$ & $\begin{array}{l}-0.007 \\
(0.014)\end{array}$ \\
\hline ers2 & $\begin{array}{l}0.072^{\star} \\
(0.042)\end{array}$ & $\begin{array}{l}0.043^{\star *} \\
(0.006)\end{array}$ & $\begin{array}{l}0.036^{* *} \\
(0.016)\end{array}$ \\
\hline fdi & $\begin{array}{c}-0.025^{\star *} \\
(0.096)\end{array}$ & $\begin{array}{l}0.012^{* *} \\
(0.061)\end{array}$ & $\begin{array}{c}0.019 \\
(0.013)\end{array}$ \\
\hline human & $\begin{array}{l}0.071^{\star *} \\
(0.028)\end{array}$ & $\begin{array}{c}0.053 \\
(0.036)\end{array}$ & $\begin{array}{c}0.035 \\
(0.019)\end{array}$ \\
\hline rd & $\begin{array}{l}0.032^{\star} \\
(0.019)\end{array}$ & $\begin{array}{c}-0.033^{* * *} \\
(0.011)\end{array}$ & $\begin{array}{c}-0.021^{\star} \\
(0.012)\end{array}$ \\
\hline $\operatorname{lnkl}$ & $\begin{array}{c}-0.065^{*} \\
(0.036)\end{array}$ & $\begin{array}{c}0.047^{\star * *} \\
(0.018)\end{array}$ & $\begin{array}{l}0.061^{\star *} \\
(0.028)\end{array}$ \\
\hline $\operatorname{lnsize}$ & $\begin{array}{c}-0.084^{*} \\
(0.044)\end{array}$ & $\begin{array}{l}0.037^{* *} \\
(0.018)\end{array}$ & $\begin{array}{l}0.048^{*} \\
(0.025)\end{array}$ \\
\hline _cons & $\begin{array}{c}0.095^{* * *} \\
(0.037)\end{array}$ & $\begin{array}{c}0.162^{* * *} \\
(0.028)\end{array}$ & $\begin{array}{c}0.132^{* * *} \\
(0.049)\end{array}$ \\
\hline $\mathrm{N}$ & 1300 & 1300 & 910 \\
\hline AR (1) test & $\begin{array}{c}-2.26 \\
{[0.000]}\end{array}$ & $\begin{array}{c}-4.85 \\
{[0.000]}\end{array}$ & $\begin{array}{c}-2.32 \\
{[0.020]}\end{array}$ \\
\hline $\mathrm{AR}(2)$ test & $\begin{array}{c}-0.58 \\
{[0.565]}\end{array}$ & $\begin{array}{c}-1.10 \\
{[0.270]}\end{array}$ & $\begin{array}{c}-1.13 \\
{[0.259]}\end{array}$ \\
\hline Sargan test & $\begin{array}{c}39.86 \\
{[0.108]}\end{array}$ & $\begin{array}{c}47.81 \\
{[0.185]}\end{array}$ & $\begin{array}{c}30.06 \\
{[0.183]}\end{array}$ \\
\hline
\end{tabular}

\subsection{Robustness Test}

Based on the method of Zhan \& Zeng (2019), this paper replaces the intensity of environmental regulation with the proportion of the output value of comprehensive utilization of three wastes in GDP. The sample data is from 2003 to 2010, and the remaining variables remain unchanged. The results are shown in Table 4. The empirical results show that the impact of environmental regulation intensity on the domestic value-added rate of exports is U-shaped regardless of whether control variables are added. The regression results of other control variables are basically consistent, which shows that the empirical test results of this paper have good robustness. 
Table 4. Robustness test results.

\begin{tabular}{|c|c|c|c|c|c|c|c|}
\hline & Model 1 & Model 2 & Model 3 & Model 4 & Model 5 & Model 6 & Model 7 \\
\hline L.dvar & $\begin{array}{c}0.882^{* * *} \\
(0.071)\end{array}$ & $\begin{array}{c}0.879^{* * *} \\
(0.061)\end{array}$ & $\begin{array}{l}0.878^{* *} \\
(0.082)\end{array}$ & $\begin{array}{c}0.867^{* * *} \\
(0.129)\end{array}$ & $\begin{array}{c}0.875^{* * *} \\
(0.085)\end{array}$ & $\begin{array}{c}0.878^{* * *} \\
(0.074)\end{array}$ & $\begin{array}{c}0.880^{* * *} \\
(0.046)\end{array}$ \\
\hline ers & $\begin{array}{c}-0.092^{\star * *} \\
(0.012)\end{array}$ & $\begin{array}{c}-0.194^{*} \\
(0.009)\end{array}$ & $\begin{array}{c}-0.021^{* *} \\
(0.011)\end{array}$ & $\begin{array}{c}-0.027^{\star} \\
(0.013)\end{array}$ & $\begin{array}{c}-0.026^{* *} \\
(0.012)\end{array}$ & $\begin{array}{c}-0.021^{\star *} \\
(0.010)\end{array}$ & $\begin{array}{c}-0.018^{\star *} \\
(0.009)\end{array}$ \\
\hline ers2 & & $\begin{array}{l}0.064^{\star} \\
(0.032)\end{array}$ & $\begin{array}{l}0.070^{\star *} \\
(0.034)\end{array}$ & $\begin{array}{l}0.084^{\star} \\
(0.047)\end{array}$ & $\begin{array}{l}0.083^{\star *} \\
(0.042)\end{array}$ & $\begin{array}{l}0.067^{*} \\
(0.036)\end{array}$ & $\begin{array}{l}0.065^{\star} \\
(0.028)\end{array}$ \\
\hline fdi & & & $\begin{array}{c}0.003 \\
(0.011)\end{array}$ & $\begin{array}{l}-0.014 \\
(0.017)\end{array}$ & $\begin{array}{c}-0.092^{\star *} \\
(0.047)\end{array}$ & $\begin{array}{c}-0.092^{* *} \\
(0.043)\end{array}$ & $\begin{array}{l}-0.058 \\
(0.007)\end{array}$ \\
\hline human & & & & $\begin{array}{l}0.034^{* *} \\
(0.016)\end{array}$ & $\begin{array}{c}0.012 \\
(0.026)\end{array}$ & $\begin{array}{c}0.011 \\
(0.027)\end{array}$ & $\begin{array}{l}0.032^{\star} \\
(0.011)\end{array}$ \\
\hline $\mathrm{rd}$ & & & & & $\begin{array}{c}-0.032^{* * *} \\
(0.009)\end{array}$ & $\begin{array}{c}-0.033^{\star * *} \\
(0.008)\end{array}$ & $\begin{array}{c}-0.034^{\star * *} \\
(0.008)\end{array}$ \\
\hline $\operatorname{lnkl}$ & & & & & & $\begin{array}{c}-0.036^{* *} \\
(0.015)\end{array}$ & $\begin{array}{c}-0.045^{* * *} \\
(0.013)\end{array}$ \\
\hline lnsize & & & & & & & $\begin{array}{c}-0.023^{*} \\
(0.122)\end{array}$ \\
\hline _cons & $\begin{array}{c}0.074^{* * *} \\
(0.072)\end{array}$ & $\begin{array}{c}0.072^{* * *} \\
(0.043)\end{array}$ & $\begin{array}{c}0.073^{* * *} \\
(0.069)\end{array}$ & $\begin{array}{c}0.054^{* * *} \\
(0.016)\end{array}$ & $\begin{array}{l}0.078^{* *} \\
(0.243)\end{array}$ & $\begin{array}{c}0.119^{* * *} \\
(0.278)\end{array}$ & $\begin{array}{c}0.131^{* * *} \\
(0.257)\end{array}$ \\
\hline $\mathrm{N}$ & 1890 & 1890 & 1890 & 1890 & 1890 & 1890 & 1890 \\
\hline $\mathrm{AR}(1)$ test & $\begin{array}{c}-8.47 \\
{[0.000]}\end{array}$ & $\begin{array}{c}-8.39 \\
{[0.000]}\end{array}$ & $\begin{array}{c}-8.36 \\
{[0.000]}\end{array}$ & $\begin{array}{c}-8.25 \\
{[0.000]}\end{array}$ & $\begin{array}{c}-8.31 \\
{[0.000]}\end{array}$ & $\begin{array}{c}-8.36 \\
{[0.000]}\end{array}$ & $\begin{array}{c}-8.02 \\
{[0.000]}\end{array}$ \\
\hline $\mathrm{AR}(2)$ test & $\begin{array}{c}-1.52 \\
{[0.130]}\end{array}$ & $\begin{array}{c}-1.13 \\
{[0.259]}\end{array}$ & $\begin{array}{c}-1.15 \\
{[0.249]}\end{array}$ & $\begin{array}{c}-1.09 \\
{[0.276]}\end{array}$ & $\begin{array}{c}-1.10 \\
{[0.273]}\end{array}$ & $\begin{array}{c}-1.06 \\
{[0.289]}\end{array}$ & $\begin{array}{c}-0.66 \\
{[0.507]}\end{array}$ \\
\hline Sargan test & $\begin{array}{c}13.25 \\
{[0.351]}\end{array}$ & $\begin{array}{c}8.12 \\
{[0.522]}\end{array}$ & $\begin{array}{c}9.267 \\
{[0.597]}\end{array}$ & $\begin{array}{c}9.524 \\
{[0.574]}\end{array}$ & $\begin{array}{c}9.263 \\
{[0.598]}\end{array}$ & $\begin{array}{c}9.539 \\
{[0.572]}\end{array}$ & $\begin{array}{c}9.376 \\
{[0.497]}\end{array}$ \\
\hline
\end{tabular}

\section{Conclusion and Enlightenment}

Firstly, this paper theoretically analyzes the impact of environmental regulations on the export of domestic value-added rate and puts forward hypotheses. Secondly, according to the input-output table of each province, this paper calculates the export domestic value-added rate of China's industries. Utilizing the panel data of 270 prefecture level and above cities in China from 2003 to 2016, this paper empirically tests the impact of environmental regulation intensity on the domestic value added rate of China's industrial exports. The results show that, in general, the impact of environmental regulation on the domestic value-added rate of export has a U-shaped feature, which verifies the hypothesis put forward in the previous paper. According to the results of sub regional regression, the impact of environmental regulation on the domestic value-added rate 
of export is the same as that of the whole, both in U-shape, while the impact of environmental regulation in western region on domestic value-added rate of export is inverted U-shaped. In the central and western regions, FDI inflow, human capital, capital intensity and enterprise size have a positive impact on the domestic value-added rate of export, while $\mathrm{R} \& \mathrm{D}$ investment and human capital have a positive impact on the domestic value-added rate of export. In the central and western regions, the impact of FDI inflow, human capital, capital intensity and enterprise size on domestic value-added rate of export is positive, while that of $\mathrm{R} \& \mathrm{D}$ investment is negative.

The policy implications of this study are as follows: 1) China should continue to increase the intensity of environmental regulation, give full play to the innovative effect of environmental regulation, offset the cost effect, improve production technology, reduce the investment in imported intermediate goods, and realize the win-win situation of environmental protection and the increase of domestic value-added rate of export. 2) When introducing foreign investment, we should have a long-term vision. 3) Make full use of $\mathrm{R} \& \mathrm{D}$ funds to promote the development of new technologies. Technological innovation is of great significance to reduce environmental pollution and increase the domestic value-added rate of exports. 4) China's economic situation is unbalanced in different regions. The unified standard of environmental regulation is not suitable for the development of various regions. The government should formulate the corresponding environmental regulation policies according to local conditions, which is conducive to the improvement of the domestic value-added rate of national exports.

\section{Conflicts of Interest}

The author declares no conflicts of interest regarding the publication of this paper.

\section{References}

Aldy, J. E., \& Pizer, W. A. (2015). The Competitiveness Impacts of Climate Change Mitigation Policies. Journal of the Association of Environmental and Resource Economists, 2, 565-595. https://doi.org/10.1086/683305

Bu, M., Liu, Z., Wagner, M., \& Yu, X. (2013). Corporate Social Responsibility and the Pollution Haven Hypothesis: Evidence from Multinationals' Investment Decision in China. Asia-Pacific Journal of Accounting \& Economics, 20, 85-99.

https://doi.org/10.1080/16081625.2013.759175

Chen, H., \& Yang, Q. (2018). Research on the Impact of Environmental Regulation on Export from the Perspective of Local Government Competition. Journal of Intertrade, 1, 12-22.

Dong, M. J., Liang, Y. M., \& Li, G. (2011). Impact of Environmental Regulation on China's Export Competitiveness-Based on the Input-Output Model. Journal of China Industrial Economics, 3, 57-67.

Elrod, A. A., \& Malik, A. S. (2017). The Effect of Environmental Regulation on PlantLevel Product Mix: A Study of EPA's Cluster Rule. Journal of Environmental Economics and Management, 83, 164-184. https://doi.org/10.1016/j.jeem.2017.03.002 
Fan, H. C., Li, Y. A., \& Yeaple, S. R. (2013). Trade Liberlization, Quality and Export Prices. SSRN Electronic Journal, 11, 12-25. https://doi.org/10.2139/ssrn.2352155

Greenstone, M., List, J. A., \& Syverson, C. (2012). The Effects of Environmental Regulation on the Competitiveness of U.S. Manufacturing. NBER Working Paper No. 18392. https://doi.org/10.3386/w18392

Hu, H. R. (2019). Can Cleaner Production Environmental Regulation Improve Product Quality? Journal of Economic Science, 3, 93-105.

Hummels, D., Ishii, J., \& Yi, K. (2001). The Nature and Growth of Vertical Specialization in World Trade. Journal of International Economics, 54, 75-96. https://doi.org/10.1016/S0022-1996(00)00093-3

Koopman, R., Wang, Z., \& Wei, S. J. (2012). Estimating Domestic Content in Exports When Processing Trade Is Pervasive. Journal of Development Economics, 99, 178-189. https://doi.org/10.1016/j.jdeveco.2011.12.004

Lanoie, P., Patry, M., \& Lajeunesse, R. (2008). Environmental Regulation and Productivity: Testing the Porter Hypothesis. Journal of Productivity Analysis, 30, 121-128. https://doi.org/10.1007/s11123-008-0108-4

Levinson, A. (1996). Environmental Regulations and Manufacturers' Location Choices: Evidence from the Census of Manufactures. Journal of Public Economics, 62, 5-29. https://doi.org/10.1016/0047-2727(96)01572-1

Li, L., \& Tao, F. (2012). Selection of Optimal Environmental Regulation Intensity for Chinese Manufacturing Industry-Based on the Green TFP Perspective. Journal of China Industrial Economics, 5, 70-82.

Li, M. J., \& Du, W. J. (2018). Environmental Regulation and Export Product Quality of Enterprises: Analysis on the Institutional Environment and Duration of Export. Journal of R\&D Management, 30, 111-120.

Li, S. G., \& Yin, H. (2017). Government Enterprise Talent Allocation and Economic Growth: An Empirical Study Based on China's City Data. Journal of Economic Research, 52, 78-91.

Li, X. P., Lu, X. X., \& Tao, X. Q. (2012). Does the Intensity of Environmental Regulation Affect the Trade Comparative Advantage of China's Industrial Industry? Journal of World Economy, 35, 62-78.

Liu, J. Y., \& Xie, J. (2018). Environmental Regulation and Export Quality Upgrading of Manufacturing: The Perspective from the Heterogeneity of Factor Input Structure. Journal of China Population, Resources and Environment, 28, 158-167.

Lu, Y. (2009). Do Environmental Regulations Influence the Competitiveness of Pollution-Intensive Products? Journal of Economic Research, 44, 28-40.

Peng, D. D., Yang, D. B., \& Su, L. M. (2016). The Impact of Environmental Regulations on the Quality Upgrade of China's Export: Evidence from Chinese Firm-Level Data. Modern Finance and Economics (Journal of Tianjin University of Finance and Economics), 36, 15-27.

Porter, M. E., \& Van der Linde, C. (1995). Toward a New Conception of the Environment Competitiveness Relationship. Journal of Economic Perspectives, 9, 97-118. https://doi.org/10.1257/jep.9.4.97

$\mathrm{Pu}, \mathrm{H}$. X. (2015). Influential Factors of Export Domestic Sophistication under the New Situation of Trade: An Empirical Test Based on China's Industrial Sectors. Journal of International Economic and Trade Research, 31, 16-29.

Shen, K. R., Jingang, \& Fang, X. (2017). Does Environmental Regulation Cause Pollution to Transfer Nearby? Journal of Economic Research, 52, 44-59. 
Sheng, D., \& Zhang, H. L. (2017). Environmental Regulations and Upgrades of Export Quality: Evidence from Two Control Zones Policy of China. Journal of Finance and Trade Economics, 38, 80-97.

Walter, I. (1982). Environmentally Induced Industrial Relocation to Developing Countries. Environment and Trade, 2, 235-256.

Wang, J., Duan, R. Z., \& Sun, X. M. (2019a). Environmental Regulation, Product Quality and Chinese Firms' Upgrading in Global Value Chain. Journal of Industrial Economics Research, No. 2, 64-75 + 101 .

Wang, Y., Huang, X. H., \& Yu, X. (2019b). Does Environmental Regulation Reduce Enterprise Export Domestic Value-Added Ratio in China? Journal of International Trade, 10, 117-131.

Wang, Z., Zhang, B., \& Zeng, H. (2016). The Effect of Environmental Regulation on External Trade: Empirical Evidences from Chinese Economy. Journal of Cleaner Production, 114, 55-61. https://doi.org/10.1016/j.jclepro.2015.07.148

Wanley, W. (1994). The Contribution of Environmental Regulations to Slowdown in Productivity Growth. Journal of Environmental Management, 8, 381-390.

https://doi.org/10.1016/0095-0696(81)90048-6

Xiao, X. J., \& Chen, Z. P. (2019). The Effect of Environmental Regulation on Sophistication of Export and Its Constraint Condition-A Study of Threshold Effect Based on Provincial Panel Data of China. Journal of Collected Essays on Finance and Economics, 10, 104-112.

Yang, S. Q. (2016). The Influence of Environmental Regulation on the Regional Heterogeneity of Export Technology Complexity. Journal of Dalian University of Technology (Social Sciences), 37, 45-51.

Zhan, X. Y., \& Zeng, F. W. (2019). Economic Competition, Environmental Pollution and High Quality Development: A Case Study of 234 Prefecture-Level Cities. Journal of Reform, 10, 119-129.

Zhang, C., Lu, M., Guo, L., Yu, T. S. (2011). The Intensity of Environmental Regulation and Technological Progress of Production. Journal of Economic Research, 46, 113-124.

Zhang, S. F., \& Bu, M. L. (2011). Environmental Regulation, Environmental Protection Investment and Productivity: An Empirical Study Based on Questionnaire of Enterprises in China. Journal of Nankai Economic Studies, 2, 129-146.

Zhang, X. Y., \& Liu, J. J. (2019). The Evolution and Orientation Choice of Environmental Regulation Policy in PRC from 1949 to 2019. Journal of Reform, 10, 16-25.

Zhang, Y. W., \& Song, L. (2019). Export Quality Effect of Environmental Regulation and Innovation: Who Plays a More Important Role in Technological Development and Technological Transformation? Journal of Economic Science, 2, 53-65.

Zheng, D. Q., \& Yu, J. P. (2014). Measurement of Value Added in China's Export Based on Firm-Level Data and Its Influencing Factors. Journal of International Trade Issues, 8, 3-13.

Zhou, K. (2015). Environmental Regulation, Regional Heterogeneity and Export Sophistication. Journal of International Business (Journal of University of International Business and Economics), 2, 17-27.

Zhu, P. F., Zhang, Z. Y., \& Jiang, G. L. (2011). Empirical Study of the Relationship between FDI and Environmental Regulation: An Intergovernmental Competition Perspective. Journal of Economic Research, 46, 133-145. 